\title{
Stability of periodontally compromised teeth after splint and non-surgical therapy: two cases followed-up for 1 to 3 years
}

\author{
Yeon-Tae Kim, Ye-Sol Park, Do-Hyung Kim, Seong-Nyum Jeong, Jae-Hong Lee* \\ Department of Periodontology, Daejeon Dental Hospital, Institute of Wonkwang Dental Research, Wonkwang University \\ College of Dentistry, Daejeon, Republic of Korea
}

This article describes cases of applying non-surgical treatment including scaling and root planing, occlusal adjustment and tooth splinting of periodontally compromised lower anterior incisors Clinical and radiographic evaluations were performed over a 1-3-year period. All clinical parameters and radiographic bone levels improved in both cases. Dramatic regeneration of alveolar bone and lamina dura were observed on radiographic images, and no specific complications occurred during the follow-up period. Within the limitations of this study, these cases demonstrated the possibility of tooth rescue through non-surgical treatment and splinting of periodontally compromised teeth typically considered for extraction. (J Dent Rehabil Appl Sci 2018;34(4):338-44)

Key words: bone regeneration; traumatic dental occlusion; occlusal adjustment; periodontal splints

\section{서론}

만성 치주염은 Porphyromonas gingivalis, Treponema denticola와 같은 특정 그람 음성 혐기성 세균에 의하여 치은 염증 및 치조골의 파괴를 동반하는 파괴적인 치주 질환으로 정의할 수 있다. ${ }^{1}$ 심도의 치주질환에 이환된 경 우 치아를 상실할 수 있으며, 치주질환에 의해서 국소적 으로 만성화된 염증은 혈관계 순환을 통한 전신적인 염 증 반응을 일으키며, 당뇨, 심혈관계 질환, 발기부전, 치 매 등의 전신질환의 악화에도 직간접적으로 영향을 미치 는 것으로 보고되고 있다..$^{2-4}$ 만성 치주염은 일반적으로 급성 통증 없이 서서히 진행되어 점진적인 치주 상태의 악화를 가져오며, 치주치료의 주요한 목적은 염증 반응 을 소실시키고 탐침 깊이와 임상 부착수준의 회복 시키 는 것에 있다. ${ }^{5}$

만성 치주염에 의하여 치아 주위 연조직과 경조직의 파

*Correspondence to: Jae-Hong Lee Assistant Professor, Department of Periodontology, Daejeon Dental Hospital, Wonkwang University College of Dentistry, 77 Dunsan-ro, Seo-gu, Daejeon, 35233 , Republic of Korea

Tel: +82-42-366-1114, Fax: +82-42-366-1115, E-mail: ljaehong@gmail.com Received: August 8, 2018/Last Revision: September 19, 2018/Accepted: October 15,2018
괴가 심할 경우에는 정상적인 교합력이 교합성 외상으로 작용하여 치아의 부착 상태에 부정적인 영향을 줄 수 있 다. 교합성 외상이라는 용어는 교합을 의미하는 단어가 아닌 외상을 의미하는 용어로 교합간섭이나 교합 부조 화 혹은 치아에 손상을 줄 수 있는 외상성 교합 등 조화 로운 교합 상태 이외의 치주조직에 외상을 주는 상태를 의미한다. ${ }^{6}$ 교합력으로 인한 치주조직이 적응하는 능력 에 영향을 주는 요소로는 교합력의 크기, 방향, 지속기간, 빈도로 나누어지며 이 힘이 치주조직의 적응능력을 벗어 나 손상을 줄 때 이것을 교합성 외상이라 명명한다. 교합 성 외상은 원인에 따라 1차성과 2차성으로 분류할 수 있 는데, 1 차성은 치주조직은 정상이나 그것을 넘어서는 과 도한 교합력이 가해질 때를 의미하며 2차성의 경우 치주 조직의 소실로 정상적인 교합력마저 조직에 손상을 가할 때를 의미한다. ${ }^{\top}$

교합이 치주질환의 파괴에 영향을 준다는 의견에 있어 
많은 연구들이 행해졌으며, Glickman 등은 zone of irritation과 zone of co-destruction에 대한 개념을 통해 염 증이 치은에만 국한될 경우 염증반응은 교합력의 영향을 받지 않으나 치주조직까지 염증이 파급시 이것을 촉진시 켜 골소실을 일으키는 co-deconstructive factor로 작용 할 수 있음을 보고하였다. ${ }^{8}$ 반면 Waerhaug 등은 부검 시 편을 통해 결합 부착상실과 치아 주위 골흡수는 치은 연 하 치태와 연관이 있으며 비외상치아에서도 외상치아와 같이 수직적 골결손이 발생할 수 있음을 보고하였다. ${ }^{9}$

이에 본 임상증례는 치주질환과 대합치 사이 조기 접 촉으로 인해 치아 동요 및 저작시 불편감이 존재하는 하 악 전치부 치아를 대상으로 비외과적 치주치료와 더불어 교합조정 및 치아고정술을 동시에 시행함으로써 소실된 치조골의 회복과 환자의 불편감을 개선시킨 두 가지 증 례를 살펴보고자 한다.

\section{증례보고}

두 증례 모두 초진 당일 임상 및 방사선학적 검사를 시 행한 뒤, 치은연상 치석제거술 및 교합 조정을 시행하였 다. 1 - 2주 뒤, 임상 검사를 시행 후, 치아고정술을 통하
여 치아의 동요도를 감소시킨 후, 적극적인 치은연하 치 근활택술을 시행하였다. 3 개월 뒤, 정기검진 시행 및 스 케일링, 6 개월 뒤 치근단 방사선 사진 촬영 및 치은연상 치석제거술을 시행하였으며, 계획된 치주 치료를 마친 뒤, 정기 검진을 시행 중에 있다(Fig. 1, Table 1).

\section{1. 증례 $A$}

2013년 3월 하악 중절치부 동요 및 저작시 통증을 주 소로 내원한 57세 여자 환자로 하악 좌측 중절치(\#31) 를 중심으로 한 치은 부종 및 발적이 관찰되었으며 \#31 원심측 탐침 깊이는 $8 \mathrm{~mm}, 2$ 도의 동요도를 보였다. 또 한, 치근단 방사선 사진상 상기 치아 치근첨부를 넘어서 는 골소실 양상 관찰되었으나 치수생활력 검사에서는 양 성반응을 보였다. 상기 치아 예후불량함을 설명하였으며 환자 동의 하에 치주치료 및 치아고정술을 진행하였다.

내원 당일 치은연상 치석제거술 및 치아고정용 강선 제 작을 위한 하악 전치부 인상채득 시행하였다. 다음 내원 시에 하악 좌우측 견치 범위에 걸쳐 강선을 이용한 치아 고정술 및 \#31 교합조정으로 안정성을 얻은 후 침윤마 취 후 치근활택술을 진행하였다. 치주치료 시행 후 상기 1st visit

2nd visit

(1 - 2 weeks) 3rd visit

(3 month follow-up) 4th visit

(6 month follow-up)

\begin{tabular}{|c|c|c|c|}
\hline $\begin{array}{l}\text { 1. Clinical and radiographic } \\
\text { examination } \\
\text { 2. Supragingival scaling } \\
\text { 3. Occlusal adjustment }\end{array}$ & $\begin{array}{l}\text { 1. Resin wire splint } \\
\text { 2. Subgingival scaling and } \\
\text { root planning }\end{array}$ & $\begin{array}{l}\text { 1. Clinical examination } \\
\text { 2. Supragingival scaling }\end{array}$ & $\begin{array}{l}\text { 1. Clinical and radiographic } \\
\text { examination } \\
\text { 2. Supragingival scaling }\end{array}$ \\
\hline
\end{tabular}

Fig. 1. Clinical parameters evaluated and the time points at which they were measured in the study.

Table 1. Clinical parameters at 1 st visit and follow up points

\begin{tabular}{|c|c|c|c|c|}
\hline & & 1st visit & 6 month follow-up & 2 year follow-up \\
\hline \multirow{4}{*}{ Case A (\#31) } & PD & $8 \mathrm{~mm}$ & $5 \mathrm{~mm}$ & $3 \mathrm{~mm}$ \\
\hline & $\mathrm{NBF}$ & - & $2 \mathrm{~mm}$ & $5 \mathrm{~mm}$ \\
\hline & BOP & + & - & - \\
\hline & & 1st visit & 6 month follow-up & 1 year follow-up \\
\hline \multirow{3}{*}{ Case B (\#41/31) } & PD & $7 \mathrm{~mm} / 6 \mathrm{~mm}$ & $4 \mathrm{~mm} / 4 \mathrm{~mm}$ & $3 \mathrm{~mm} / 3 \mathrm{~mm}$ \\
\hline & $\mathrm{NBF}$ & - & $3 \mathrm{~mm} / 2 \mathrm{~mm}$ & $3 \mathrm{~mm} / 2 \mathrm{~mm}$ \\
\hline & $\mathrm{BOP}$ & + & - & - \\
\hline
\end{tabular}

PD: probing depth, NBF: new bone formation, BOP: bleeding on probing. 

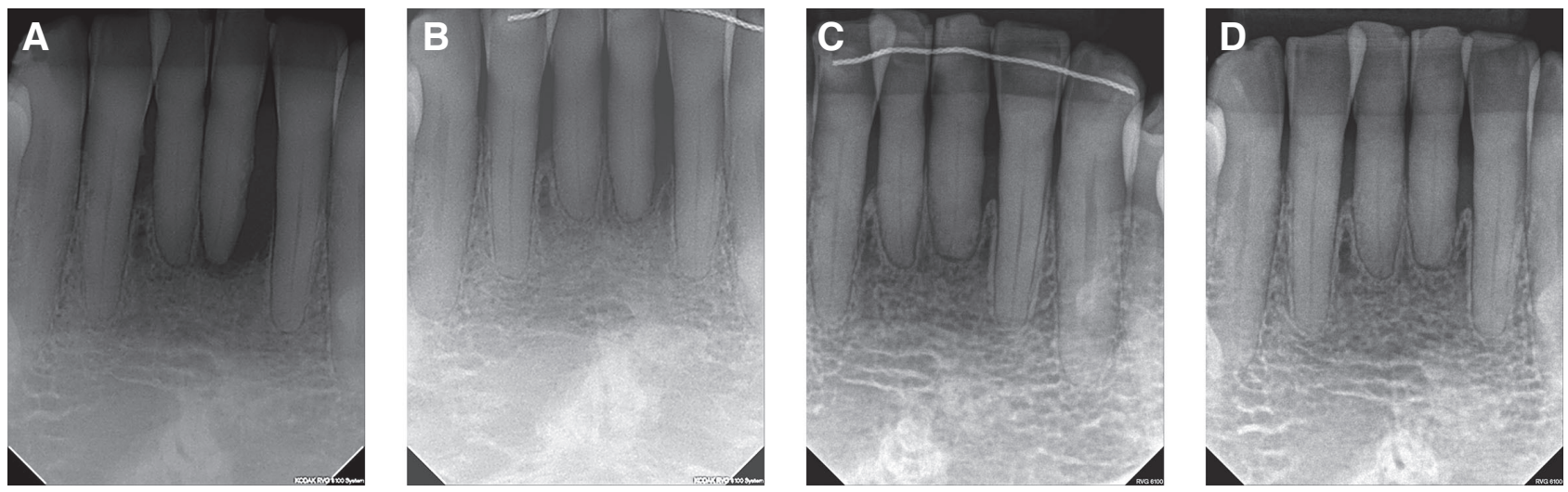

Fig. 2. Periapical radiography: (A) Initial radiography showing a periapical radiolucency and severe bone loss of the mandibular left central incisor, which has subgingival calculus deposition. (B - D) Follow up, 6 months (B), 2 years (C), 3 years (D) after periodontal treatment and occlusal adjustment with resin wire splint.

부위 치은 부종 및 탐침시 출혈 감소, 그리고 불편감 역시 감소되었으나 설측부위 부종 잔존하는 형태 보였다. 전 악 치주 치료를 위한 1 - 2주 간격의 치근활택술 시행 시, 치은 부종 및 출혈 양상이 지속적인 감소함을 확인할 수 있었다.

6개월 뒤 정기 검진 시, 유지관리를 위한 치은연상 치 석제거술 및 치근단 방사선 사진 촬영하였으며 \#31 원심 측 탐침깊이 $5 \mathrm{~mm}$ 로 감소하였고 치근첨부를 포함한 치 조골이 $2 \mathrm{~mm}$ 회복된 양상이 관찰되었다. 2년 뒤 탐침깊 이 $3 \mathrm{~mm}$ 로 감소하였으며 치근단 방사선 사진에서 치근 첨부에서 $5 \mathrm{~mm}$ 의 치조골 높이 및 부착수준 회복을 보였 으며 상부에 명백한 치조백선이 관찰되었다. 3년 후 하악 전치부 치아 고정용 강선이 제거된 상태로 환자 내원하 였으며 하악 좌측 중절치 동요도는 $0-1$ 도를 보이는 상 태로 치근단 방사선 사진상 골 높이는 2 년 전과 큰 차이 없이 안정적인 유지를 보였다(Fig. 2).

\section{2. 증례 $B$}

2016년 8월, 하악 좌우측 중절치(\#31,41)의 동요도와 불편감을 주소로 내원한 46세 남자 환자로 만성 중증 치 주염에 의한 심한 골파괴 양상과 치은의 부종 및 발적, 조 기 교합접촉이 관찰되었고 탐침 깊이는 \#41 협측 $7 \mathrm{~mm}$, \#31 협측 $6 \mathrm{~mm}$ 였으며 치아 동요도는 두 치아 모두 2도 로 측정되었다. 치근단 방사선 사진에서 \#41 근심측 잔 존치조골은 $3 \mathrm{~mm}$, \#31 근심은 $5 \mathrm{~mm}$ 로 파악되었다.

내원 당일 치은연상 치석제거술과 상기 치아에 대한 교 합조정 및 강선을 동반한 치아고정술을 위한 인상채득을 시행하였고 다음 내원 시에 하악 좌우측 견치 $\# 33=43)$ 범위에 걸쳐 치아고정술을 시행하여 안정성을 얻은 후, 침윤마취 및 치근활택술을 시행하였다. 치근활택술 시행 2주 후 재평가 시행시, 하악 좌측 중절치 강선이 부분 탈 락하여 재접착 하였으며 치은 부종 및 탐침시 출혈 양상
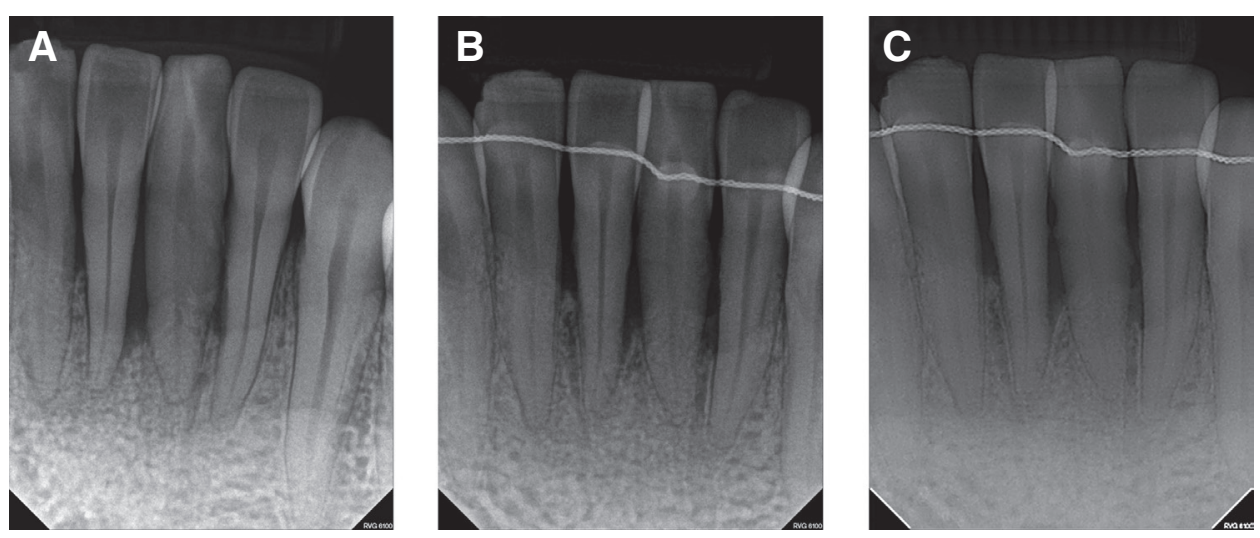

Fig. 3. Periapical radiography: (A) Initial radiography showing a severe bone loss of the both mandibular central incisors, which have subgingival calculus deposition. (B, C) Follow up, 6 months (B), 1 year (C) after periodontal treatment and occlusal adjustment with resin wire splint. 
감소하였으며 \#31, 41의 협측 탐침깊이 또한 $4 \mathrm{~mm}$ 로 측 정되었으나 하악 전치부 설측 치석의 지속적 침착 관찰되 어 유지관리를 위해 1 - 2달 간격의 치은연상 치석제거술 및 치근활택술을 시행하였다.

6개월 뒤, 정기 검진 시 치근단 방사선 사진 촬영하였으 며 \#41 근심측 잔존 치조골 $6 \mathrm{~mm}$, \#31 근심은 $7 \mathrm{~mm}$ 로 치조골의 회복 및 상부에 명백한 치조백선이 관찰되었다. 1 년 뒤 치근단 방사선 사진에서도 치조골 높이와 치조백 선이 안정적으로 유지됨을 확인할 수 있었다(Fig. 3).

\section{고찰}

미국치주병과학회에서는 저작력에 동요를 보이는 치 아, 이차 외상성 교합을 받는 치아, 치아의 쓰러짐이나 정 출을 막아야 하는 경우, 재생적 치주수술 이후 동요가 존 재하는 치아, 교정치료 이후 치아를 안정시켜야 하는 경 우를 일반적으로 치아 간 고정술의 적응증으로 언급하였 다. ${ }^{10} 2001$ 년 Davies 등은 교합조정과 치주치료에 반응하 지 않는 증가된 동요를 보이는 치아를 안정시키는 경우, 치조골이 감소하고 치주인대의 폭경이 증가되어 점진적 으로 증가되는 치아 동요를 보일 경우 치아고정술이 주 요 치료 방법 중 하나가 될 수 있으며 치아고정술을 통하 여 저작 시 불편감이 해소되고 저작 기능의 개선이 가능 하다고 보고하였다. ${ }^{11}$ 반면, 1999년 Pollock 등은 중등도 또는 심도의 동요도를 보이는 치아가 치료되지 않는 치 주염증, 일차 교합성 외상과 함께 존재하는 경우, 일차 교 합성 외상이 존재하지만 교합조정이 먼저 이루어지지 않 은 경우, 동요도가 존재하는 치아를 안정화시키기 위한 충분한 수의 비동요 치아가 존재하지 않는 경우, 마지막 으로 구강위생이 불량한 경우를 치아고정술에 대한 금기 증으로 언급하였다. ${ }^{12}$

오랜 기간 치주질환으로 인한 치조골 소실을 보이는 치아에 대한 치아고정술은 논쟁이 되었으나, 여러 선행연 구들을 통하여 치아의 동요를 감소시키고 교합의 안정을 도모하기 위한 치아고정술은 치은염과 치주염의 진행 및 치주낭 형성을 억제하는데 효과가 있을 수 있음이 제시 되었다. Polson과 Lindhe 등은 교합성 외상이 치주질환 을 개시하지는 않으며 교합성 외상이 오랜 시간 가해질 경우 치주염으로 인한 치조골 파괴를 가속화한다고 공 통적으로 지적하였다. ${ }^{13,14}$ Philstrom 등은 20 - 40대 환자 의 제 1 대구치를 대상으로 교합성 외상의 징후와 심도를 조사하였고 치은 출혈, 깊은 치주낭 형성, 치아 주위 치조
골의 소실, 과도한 동요도나 치주인대강 확장과 같이 교 합성 외상의 징후가 보이는 치아의 경우 더 깊은 치주낭 과 부착소실이 관찰되었다고 보고하였다. ${ }^{15}$ 이러한 내용 을 종합해 봤을 때, 교합력이 치주질환의 원인이라고 보 기는 어려우나 치주질환의 개시와 진행에 관여하는 위험 요인이라는 점을 알 수 있다.

치주질환은 교합력 뿐 아니라 구강 위생 관리 정도, 치 은 두께 및 각화 치은의 양, 치조골의 외형, 보철의 형태 등의 여러 해부학적 및 의원적 요인들이 복합적으로 작 용하기 때문에, 교합력만을 주된 원인으로 보기에는 한 계가 있다. 이번 증례들 또한 인과관계는 알 수 없으나 치주질환으로 인해 감소된 치주조직을 가지는 하악 전치 부에서 2차 교합성 외상이 동반된 경우로 판단할 수 있 으며 이를 개선하기 위해 교합조정, 치아고정술, 및 치주 치료를 시행하였다. 두 가지 증례 모두에서 발적과 부종 이 소실되었으며 첫번째 증례에서는 하악 좌측 중절측 원심측에서 치근단 방사선 사진상 치근단을 넘어서 소실 되었던 치조골이 치근단 상방 $5 \mathrm{~mm}$ 까지 치조골 회복을 보였고 상방 치조골 치조백선의 회복을 관찰할 수 있었 다. 두번째 증례에서도 하악 좌우측 중절치 근심에서 치 근단 방사선 사진상 $3-4 \mathrm{~mm}$ 의 치조골 회복 및 상방부 치조백선의 회복을 볼 수 있었다.

Lemmerman 등은 치아 간 치아고정술이 occlusal rest 를 제공함으로써 기존에 존재하던 치주질환을 악화시키 는 교합 요소를 제거하거나 완화시킬 수 있다고 하였고, 치아 장축 방향으로 교합압을 유도할 수 있음을 확인하 였다. ${ }^{16}$ 여기에 더하여, 지지가 약화된 치아를 안정화 시 켜 가해지는 힘에 대한 저항을 증가시키며 국소적으로 과도한 힘이 가해지는 것을 막음으로써 추가적인 골소실 을 막을 수 있음을 보고하였다. Ramfjord 또한 동요가 존 재하는 치아를 고정 했을 때 측방력은 대부분 강선을 통 해 인접치아로 전달되고 수직적인 분력만이 해당 치아의 치주조직으로 전달되며 이 수직적인 분력은 치아가 받는 힘 중 비교적 유리한 힘의 형태라 보고하였다. ${ }^{17}$ 이번 연 구의 증례는 모두 하악 전치부에 해당하는 사항으로 하 악 전치부의 경우 구치부나 견치에 비해 비교적 교합의 영향을 적게 받기 때문에 교합조정에 있어서 이점이 존재 한다. 중심위로 폐구시 조기접촉이 존재할 경우, 측방운 동시 교합간섭이 있다면 제거가 필요하다. 또한 치아 고 정술 또한 하악 전치부의 경우 설측에 강선을 적용할 경 우 치태 및 치석 침착에 있어 불리한 면이 존재하기 때문 에 심미적인 문제가 심하게 저해되지 않는다면 협측에 적 
용하는 것이 추천된다.

이번 증례에서 치아의 치주 상태를 진단하기 위해 치근 단 방사선 사진이 사용되었고 이는 단일 치아의 평가에 있어 파노라마 방사선 사진 보다 좀 더 자세한 정보를 얻 을 수 있으며 비교적 사진 왜곡이 덜하다는 장점이 존재 한다. 하지만 치근단 방사선 사진 또한 각도의 차이로 인 한 치아 및 치조골 높이에 대한 왜곡이 존재할 수 있어 주 의가 필요하다. ${ }^{18}$ 이번 연구에서는 XCP 기구를 이용하여 평행촬영을 시행하였으며 이를 통해 치근단 방사선 사진 의 왜곡을 최소화 하였다. Cone beam형 전산화단층영상 등 더 정확한 방사선학적 진단 기구 또한 존재하나 방사 선 조사량이나 비용적인 측면을 생각할 때 단일 치아의 평가에 있어 치근단 방사선 사진은 치주상태의 적절한 진단과 평가에 필수적으로 고려된다.

\section{결론}

치주질환의 진행과 비생리적인 교합압의 복합적인 작 용으로 인해 치조골의 파괴가 지속적으로 진행되어 치아 의 동요 및 저작시 불편감이 발생할 때 일반적인 보존적, 수술적 치주치료에 더하여 치아고정술을 이용한 치아지 지가 더해질 경우, 이번 증례들와 같이 예후가 불량한 치 아임에도 환자와 술자 모두 만족할만한 예지성 있는 치 료결과를 도모할 수 있을 것으로 고려된다.

\section{Acknowledgements}

This research was supported by Basic Science Research Program through the National Research Foundation of Korea (NRF) funded by the Ministry of Science, ICT \& Future Planning (NRF-2017R1C1B5014849).

\section{ORCID}

Jae-Hong Lee https://orcid.org/0000-0002-2375-0141

\section{References}

1. Genco RJ. Host Responses in Periodontal Diseases: Current Concepts. J Periodontol 1992;63:4 Suppl:338-55.

2. Lee JH, Oh JY, Choi JK, Kim YT, Park YS, Jeong SN, Choi SH. Trends in the incidence of tooth extraction due to periodontal disease: results of a 12-year longitudinal cohort study in South Korea. J Periodontal Implant Sci 2017;47:264-272.

3. Lee JH, Lee JS, Park JY, Choi JK, Kim DW, Kim YT, Choi SH. Association of Lifestyle-Related Comorbidities With Periodontitis: A Nationwide Cohort Study in Korea. Medicine (Baltimore) 2015;94:e1567.

4. Lee JH, Oh JY, Youk TM, Jeong SN, Kim Y'T, Choi $\mathrm{SH}$. Association between periodontal disease and non-communicable diseases: A 12-year longitudinal health-examinee cohort study in South Korea. Medicine (Baltimore) 2017;96:e7398.

5. Branschofsky M, Beikler T, Schäfer R, Flemming TF, Lang H. Secondary trauma from occlusion and periodontitis. Quintessence Int 2011;42:515-22.

6. Hallmon WW, Harrel SK. Occlusal analysis, diagnosis and management in the practice of periodontics. Periodontol 2000 2004;34:151-64.

7. Jin LJ, Cao CF. Clinical diagnosis of trauma from occlusion and its relation with severity of periodontitis. J Clin Periodontol 1992;19:92-7.

8. Glickman I, Smulow JB. Further observations on the effects of trauma from occlusion in humans. J Periodontol 1967;38:280-93.

9. Waerhaug J. The infrabony pocket and its relationship to trauma from occlusion and subgingival plaque. J Periodontol 1979;50:355-65.

10. Smiley CJ, Tracy SL, Abt E, Michalowicz BS, John MT, Gunsolley J, Cobb CM, Rossmann J, Harrel SK, Forrest JL, Hujoel PP, Noraian KW, Greenwell H, Frantsve-Hawley J, Estrich C, Hanson N. Systematic review and meta-analysis on the nonsurgical treatment of chronic periodontitis by means of scaling and root planing with or without adjuncts. J Am Dent Assoc 2015;146:508-24.

11. Davies SJ, Gray RJ, Linden GJ, James JA. Occlusal considerations in periodontics. Br Dent J 2001;191:597-604.

12. Pollack RP. Non-crown and bridge stabilization of severely mobile, periodontally involved teeth. A 25year perspective. Dent Clin North Am 1999;43:77103.

13. Polson AM, Kennedy JE, Zander HA. Trauma and progression of marginal periodontitis in squirrel monkeys. I. Co-destructive factors of periodontitis 
and thermally-produced injury. J Periodontal Res 1974;9:100-7.

14. Lindhe J, Ericsson I. The effect of elimination of jiggling forces on periodontally exposed teeth in the dog. J Periodontol 1982;53:562-7.

15. Pihlstrom BL, Anderson KA, Aeppli D, Schaffer EM. Association between signs of trauma from occlusion and periodontitis. J Periodontol 1986;57:16.

16. Lemmerman K. Rationale for stabilization. J Periodontol 1976;47:405-11.
17. Ramfjord SP, Ash MM Jr. Significance of occlusion in the etiology and treatment of early, moderate, and advanced periodontitis. J Periodontol 1981;52:511-7.

18. Rushton VE, Horner K, Worthington HV. Routine panoramic radiography of new adult patients in general dental practice: relevance of diagnostic yield to treatment and identification of radiographic selection criteria. Oral Surg Oral Med Oral Pathol Oral Radiol Endod 2002;93:488-95. 


\section{Splint 및 비외과적 치주치료를 통하여 치주질환에 이환된 치아의 안정화 증례 보고}

\section{김연태, 박예솔, 김도형, 정성념, 이재홍*}

원광대학교 치과대학 대전치과병원 치주과

본 증례는 치주적으로 이환된 하악 전치부를 치은연상 치석제거술과 치근활택술을 포함한 비외과적 치주치료, 교합 조 정 및 치아 간 치아고정술을 통해 회복한 경우이다 임상적, 방사선학적 평가를 술 후 1 - 3년간 시행하였다. 두 증례 모두 임상적 계측치에서 향상된 결과를 보였고 방사선학적 평가에서 현저한 치조골 및 치조백선의 재생이 관찰되었다. 이번 증례는 발치가 고려되는 심도의 치주질환에 이환된 치아에서 비외과적 치주치료와 치아고정술을 통해 치아를 보존할 수 있는 가능성을 보여준 사례로 보고하는 바이다.

(구강회복응용과학지 2018;34(4):338-44)

주요어: 골재생; 교합성 외상; 교합 조정; 치아고정술

*교신저자: 이재홍

(35233)대전 서구 둔산로 77 원광대학교 치과대학 대전치과병원 치주과

Tel: 042-366-1114 | Fax: 042-366-1115 | E-mail: ljaehong@gmail.com

접수일: 2018년 8월 8일 | 수정일: 2018년 9월 19일 | 채택일: 2018년 10월 15일 